\title{
Bone quality of laying hens fed different levels of fiber in the growth phase (7 to 17 weeks of age $)^{1}$
}

\author{
Carlos Eduardo Braga $\mathrm{Cruz}^{2}$, Ednardo Rodrigues Freitas ${ }^{3}$, Nadja Naiara Pereira Farias ${ }^{4}$, Regina \\ Patrícia de Souza Xavier ${ }^{4}$, Jayron dos Santos Correia Lima ${ }^{4}$, Newton Lima Sá ${ }^{4}$, Nádia de Melo \\ Braz $^{2}$, Roseane Madeira Bezerra²
}

\footnotetext{
${ }^{1}$ Research financed by CNPq.

2 Programa de Pós-graduação em Zootecnia da UFC, Fortaleza/CE, Brazil.

${ }^{3}$ Departamento de Zootecnia da UFC, Fortaleza/CE, Brazil.

${ }^{4}$ Curso de Zootecnia da UFC, Fortaleza/CE, Brazil.
}

\begin{abstract}
The effects of neutral detergent fiber levels (NDF) $(145,165,185 \mathrm{~g} / \mathrm{kg}$ ) were assessed on the bone quality of light-weight and medium-weight laying hens. Eight hundred and forty laying hens were distributed in a completely randomized design in a $2 \times 3$ factorial arrangement (two strains and three NDF levels) with four replications of 35 birds. At the end of the growth phase, birds were transferred to a laying shed in the same experimental design and each experimental plot consisted of 14 birds. For bone assessment, two birds were selected per plot in the 17th week and one bird in the 35th week for slaughter. After slaughter, drumstick and thigh (legs) were removed and after deboning of the femur and tibia, taken to measurement of their length, weight, Seedor index, resistance, deformity, dry matter, mineral residue and crude protein. The data analysis showed no significant interaction between the factors NDF level and strain for any of the variables assessed at the different phases. The NDF level in the diet did not significantly influence bone growth, quality and composition at the end of the growing and laying phases. Medium-weight birds presented larger and heavier femur and tibia, with a greater Seedor index and less deformity, ash content and protein than the light-weight birds. Resistance did not vary significantly among the strains. A diet intended for laying hens at the growth phase can contain up to $185 \mathrm{~g} / \mathrm{kg}$ NDF without causing problems in bone development and quality of laying hens.
\end{abstract}

Key Words: alternative feedstuff, bone resistance, Seedor index

\section{Introduction}

The factors that can interfere with obtaining laying hens with the required quality to start laying include especially a feeding program that allows proper bone and muscle development in the growth phase, because alterations in nutrition can have direct influence on bone growth and quality in birds (Rath et al., 2000).

It is usual to include fibrous feedstuffs in growth diets for laying hens. This practice aims to maintain low diet density, increase the time spent feeding and thus prevent excessive weight gain (Scheideler et al., 1998) and reduce bird loss from cannibalism (Aerni et al., 2000; El-Lethey et al., 2000).

Although the practice of using fibrous feedstuffs apparently has benefits, there are other concerns regarding its effects. Rath et al. (2000) reported that higher levels of fiber in diets for laying hens can reduce calcium absorption in the intestines, leading to blood hypocalcaemia, which could contribute to reducing bone development or resistance. However, for González-Alvarado et al. (2007), the traditional concept that birds should receive diets with little fiber to prevent reduced nutrient digestibility and performance should change because including fiber in the diet can benefit bird performance.

Several methods have been used to quantify the fibrous fraction in feedstuffs. Warpechowski (2005) reported that the effects of fiber in monogastric animals were associated mainly with the fractions not considered in the calculation of the crude fiber.

Thus, the crude fiber method was gradually replaced with acid detergent fiber (ADF) and neutral detergent fiber (NDF) developed by Van Soest \& Wine (1967). According to Jeraci \& Van Soest (1990), NDF can be an important measure to characterize the effects of fiber in poultry diets.

Therefore, the objective of the present research was to assess the effect of fiber levels in growth diets (7th to 17th week) on bone quality of light-weight and medium-weight laying hens at the end of the growth phase and in the laying phase. 


\section{Material and Methods}

To conduct the experiment, 1000 day-old chicks were acquired, half from a commercial light-weight laying hen strain (Lohman LSL) and the other from a medium-weight laying hen strain (Hy Line Brown).

In the initial phase (up to the 6th week), birds were housed on the floor of a conventional rearing shed and received management following the recommendations contained in the manual for each strain for the phase. After the 6th week, birds were weighed and selected for obtainment of experimental plots with a uniform average weight of 520.27 and $532.34 \mathrm{~g} / \mathrm{bird}$ in the 7th week (lightweight and medium-weight birds, respectively), following recommendations by Sakomura \& Rostagno (2007).

To carry out the experiment, 814 birds were used in the growth phase, between the 7 th and 17 th weeks. They were distributed in a completely randomized experimental design in a $2 \times 3$ factorial arrangement, of two strains $\times$ three NDF levels, with four replications of 35 birds. The NDF levels tested were 145,165 and $185 \mathrm{~g} / \mathrm{kg}$.

Birds were housed in galvanized wire growth cages $(50 \times 50 \times 45 \mathrm{~cm})$, which had a galvanized iron guttertype feeder and a nipple-type drinker. The total number of birds in each block was divided according to cage capacity, housing seven birds per cage, totaling five cages per plot.

Birds were vaccinated following the vaccination program elaborated according to the health challenges of the region.

Daily, throughout the experimental period, the temperature and relative humidity in the air inside the shed were measured with a maximum minimum thermometer and a hygrometer, respectively. The data were recorded daily and readings made at 8 a.m. and 4 p.m. At the end of experiment, the means of the maximum $\left(31.9 \pm 1.75{ }^{\circ} \mathrm{C}\right)$ and minimum $\left(26.9 \pm 1.78^{\circ} \mathrm{C}\right)$ temperatures and relative air humidity $(78 \%)$ were calculated.

In the initial phase (up to the 6th week), the same diet was used for the birds of both lines, because of the similarities between the nutritional requirement values recommended in the management manuals for each rearing phase. When formulating the diets, the feedstuff composition values proposed by Rostagno et al. (2005) were considered. The diets of the experimental phase were formulated to contain the same amount of nutrients, except for the NDF level (Table 1).

The light program in the growth phase was 23 hours of light in the first week, which was reduced by one hour each week until natural light at the end of the 6th week, and birds remained under natural light until the 17 th week.
Birds were weighed weekly throughout the experimental phase ( 7 to 17 weeks of age). In the 17 th week, after the weekly weighing, two of the birds were selected per plot, with weights similar to the mean weight of each plot. After identification, birds were slaughtered by cervical displacement and the drumsticks and thighs (legs) were removed, identified, weighed and frozen.

To remove the bones, the pieces were thawed, weighed, identified and immersed in boiling water for 10 minutes. Bones were then removed using a scalpel, according to methodology reported by Bruno (2002).

The femur and tibia length and weight were measured using a digital caliper and precision scales (0.01 g), respectively. Bone density, in $\mathrm{mg} / \mathrm{mm}$, was measured by the Seedor index, obtained by dividing the value of weight $(\mathrm{mg} / \mathrm{mm})$ by the length $(\mathrm{mg} / \mathrm{mm})$ of the bone assessed (Seedor, 1991).

Bone resistance and deformity parameters were determined in the bone in natura (tibia and femur) using a mechanical press. The bone was placed horizontally on a wooden support, secured at each end and with a compression force applied by a piston on the central point of each bone. The descent speed of the piston was $1.223 \mathrm{~mm} / \mathrm{min}$. The maximum quantity of force applied on the bone before its fracture was considered fracture resistance $\left(\mathrm{kgf} / \mathrm{cm}^{2}\right)$, measured by a digital extensometer. The deformity $(\mathrm{mm})$ was also measured by an extensometer at the time of bone fracture.

The right bones from the tibia and the femur were thawed, weighed and placed in a forced ventilation chamber at $55^{\circ} \mathrm{C}$ for 72 hours. Samples were then removed from the chamber and weighed again for obtainment of the pre-dry matter. Bones were ground in a ball mill, packed and labeled for further determination of dry matter (DM), mineral matter (MM) and crude protein (CP). Methodologies by Silva \& Queiroz (2002) were used.

At the end of the growth phase, birds were transferred to the laying shed, kept in the same experimental design used in the growth phase, and each experimental plot consisted of 14 birds. In this phase, birds were distributed in galvanized wire cages $(0.25 \times 0.45 \times 0.40 \mathrm{~m})$ equipped with a galvanized iron feeder and automatic drinker containing a valve attached to the bowl at a density of two birds/cage.

The experimental period, at this phase, lasted until the 35 th week of age, and this period was divided into 28-day periods.

The light program used was 14 hours light/day shortly after transference (18 weeks of age) to the laying shed. After the following week (19 weeks) there were seven weekly increases of $15 \mathrm{~min}$ light/day until 16 light hours 
were reached, remaining constant until the end of the experiment.

All birds were fed freely, with the same laying diet throughout the whole production phase. The diet was formulated based on corn and soybean meal, considering the feedstuff composition values proposed by Rostagno et al. (2005) and requirements according to recommendations in the management manuals for each rearing phase.

To assess the bone quality of the laying hens, one bird was slaughtered per plot in the 35 th week of age, and all the sample preparation procedures and measuring methodologies of the variables used in the previous phase were adopted.

The data for bone composition and quality in the 17 th and 35 weeks were analyzed using the ANOVA module of SAS (Statistical Analysis System, version 9.1) for a factorial model, and means were compared by the SNK test (5\%).

\section{Results and Discussion}

The statistical analysis of the data showed that there was no significant interaction between the factors NDF and strain for all the variables assessed at the end of the growth phase. Regarding the effect of fiber level, it was observed that the NDF level in the diet did not significantly influence femur and tibia growth, quality and composition in laying hens in the 17 th week of age (Table 2).

It is consensus that bird growth depends on nutrient availability for the metabolic processes and that nutrients should be ingested with diet, digested and absorbed. Thus, if there is reduced mineral ingestion or digestibility in the diet, especially calcium and phosphorus, problems in bone tissue growth and quality can occur (Rath et al., 2000).

Thus, expectations were raised as to how increase in the NDF level in the diet might influence bone growth or

Table 1 - Calculated feed and chemical composition of the experimental diets used for commercial laying hens in the growth and laying phases

\begin{tabular}{|c|c|c|c|c|c|c|c|c|}
\hline \multirow{3}{*}{ Ingredients } & \multirow{3}{*}{$1-6$ weeks } & \multicolumn{6}{|c|}{ Neutral detergent fiber levels (g/kg) } & \multirow{3}{*}{$\begin{array}{c}\text { Laying } \\
\text { phase }\end{array}$} \\
\hline & & \multicolumn{3}{|c|}{7 - 12 weeks } & \multicolumn{3}{|c|}{$13-17$ weeks } & \\
\hline & & 145 & 165 & 185 & 145 & 165 & 185 & \\
\hline Corn & 640.0 & 605.7 & 573.6 & 485.9 & 610.7 & 589.2 & 551.0 & 609.0 \\
\hline Soybean meal & 320.0 & 231.3 & 215.1 & 247.9 & 195.5 & 178.6 & 163.4 & 267.5 \\
\hline Wheat bran & 0.0 & 106.3 & 170.4 & 205.0 & 117.5 & 178.8 & 244.2 & 0.0 \\
\hline Soybean oil & 0.0 & 0.0 & 3.4 & 23.9 & 0.0 & 0.0 & 5.2 & 11.4 \\
\hline Inert & 0.0 & 18.8 & 0.0 & 0.0 & 39.4 & 16.9 & 0.0 & 0.0 \\
\hline Monodicalcium phosphate & 18.4 & 15.8 & 15.1 & 14.4 & 15.5 & 14.8 & 14.2 & 17.1 \\
\hline Limestone & 13.4 & 15.1 & 15.4 & 15.6 & 15.5 & 15.8 & 16.1 & 87.4 \\
\hline Salt & 3.5 & 3.6 & 3.6 & 3.6 & 3.7 & 3.7 & 3.7 & 3.4 \\
\hline DL-methionine & 0.7 & 1.4 & 1.4 & 1.4 & 0.7 & 0.7 & 0.7 & 1.7 \\
\hline Vitamin + mineral supplement ${ }^{1}$ & 4.0 & 0.0 & 0.0 & 0.0 & 0.0 & 0.0 & 0.0 & 0.0 \\
\hline Vitamin mixture & 0.0 & $1.0^{2}$ & $1.0^{2}$ & $1.0^{2}$ & $1.0^{2}$ & $1.0^{2}$ & $1.0^{2}$ & $2.0^{3}$ \\
\hline Mineral mixture ${ }^{4}$ & 0.0 & 0.5 & 0.5 & 0.5 & 0.5 & 0.5 & 0.5 & 0.5 \\
\hline L-lysine $\mathrm{HCl}$ & 0.0 & 0.5 & 0.7 & 0.7 & 0.0 & 0.0 & 0.0 & 0.0 \\
\hline Total & 100 & 100 & 100 & 100 & 100 & 100 & 100 & 100 \\
\hline \multicolumn{9}{|c|}{ Calculated chemical composition } \\
\hline Metabolizable energy (kcal/kg) & 2.920 & 2.800 & 2.800 & 2.800 & 2.750 & 2.750 & 2.750 & 2.800 \\
\hline Crude protein $(\mathrm{g} / \mathrm{kg})$ & 201.0 & 175.0 & 175.0 & 175.0 & 160.0 & 160.0 & 160.0 & 175.0 \\
\hline Crude fiber $(\mathrm{g} / \mathrm{kg})$ & 31.4 & 35.0 & 39.2 & 43.8 & 34.0 & 38.0 & 42.3 & 27.7 \\
\hline Neutral detergent fiber $(\mathrm{g} / \mathrm{kg})$ & 118.4 & 145.0 & 165.0 & 185.0 & 145.0 & 165.0 & 185.0 & 107.4 \\
\hline Acid detergent fiber $(\mathrm{g} / \mathrm{kg})$ & 46.8 & 50.7 & 55.6 & 60.5 & 49.0 & 54.0 & 59.1 & 41.7 \\
\hline Calcium $(\mathrm{g} / \mathrm{kg})$ & 10.0 & 10.0 & 10.0 & 10.0 & 10.0 & 10.0 & 10.0 & 38.0 \\
\hline Available phosphorus (g/kg) & 4.7 & 4.3 & 4.3 & 4.3 & 4.0 & 4.0 & 4.0 & 4.3 \\
\hline Sodium $(\mathrm{g} / \mathrm{kg})$ & 1.8 & 1.8 & 1.8 & 1.8 & 1.8 & 1.8 & 1.8 & 1.7 \\
\hline Total lysine $(\mathrm{g} / \mathrm{kg})$ & 10.5 & 9.0 & 9.0 & 9.0 & 8.0 & 8.0 & 8.0 & 9.0 \\
\hline Total methionine $(\mathrm{g} / \mathrm{kg})$ & 4.8 & 4.1 & 4.1 & 4.1 & 3.0 & 3.0 & 3.0 & 4.5 \\
\hline Total methionine + cystine $(\mathrm{g} / \mathrm{kg})$ & 8.1 & 7.1 & 7.1 & 7.1 & 6.0 & 6.0 & 6.0 & 7.3 \\
\hline Total threonine $(\mathrm{g} / \mathrm{kg})$ & 7.8 & 6.6 & 6.6 & 6.6 & 6.0 & 6.0 & 6.0 & 6.8 \\
\hline Total tryptophan (g/kg) & 2.5 & 2.0 & 2.0 & 2.0 & 1.9 & 1.9 & 1.9 & 2.1 \\
\hline Linoleic acid $(\mathrm{g} / \mathrm{kg})$ & 14.5 & 14.8 & 16.9 & 27.4 & 15.0 & 15.0 & 18.2 & 19.7 \\
\hline
\end{tabular}

${ }^{1}$ Mineral vitamin supplement (composition per kg product): vit. A - 1,775,000 IU; vit. B12 - 2,280 mcg; vit D3 - $450,000 \mathrm{IU}$; vit. E - 2,275 mg; vit. K - 325 mg; folic acid - 113 mg; niacin - 5,750 mg; pyridoxine - $450 \mathrm{mg}$; colistin - 1,750 mg; riboflavin - 1,125 mg; thiamine - $450 \mathrm{mg}$; calcium pantothenate - 2,275 mg; choline - $66,000 \mathrm{mg}$; biotin - $11.30 \mathrm{mg}$; antioxidant - $500 \mathrm{mg}$; Silicate - 10,000 mg; Co - 25.00 mg; Cu - 2,500 mg; Fe - 6,250 mg; I - $260 \mathrm{mg}$; Mn - 13,000 mg; methionine - $225 \mathrm{~g}$; Se - $45.00 \mathrm{mg}$; Zn - 11,100 mg.

${ }^{2}$ Vitamin supplement for growth (composition per kg product): vit. A - 6,000,000 IU; vit. D3 - 2,000,000 IU; vit. E - 12,000 mg; vit. K3 - 2,000 mg; vit. B1 - 2,200 IU; vit. B2 -

5,000; vit B6 - 2,300 mg; vit. B12 - 12,000 mcg; niacin - 28,000 mg; folic acid - $600 \mathrm{mg}$; pantothenic acid - 11,000 mg; antioxidant - $15 \mathrm{mg}$; biotin - $20 \mathrm{mg}$; selenium - $200 \mathrm{mg}$.

${ }^{3}$ Vitamin supplement (composition per kg product): vit. A - 7,000,000 IU; vit. D3 - 3,300,000 IU; vit. E - 11,000 mg; vit. K3 - 2,000 mg; vit. B1 - 2,200 IU; vit. B2 - 7,700;

vit B6 - 2,200 mg; vit. B12 - 11,000 mcg; niacin - 26,000 mg; folic acid - $552 \mathrm{mg}$; pantothenic acid - 13,000 mg; biotin - $112 \mathrm{mg}$; antioxidant - $15 \mathrm{mg}$; selenium - $150 \mathrm{mg}$.

${ }^{4}$ Mineral supplement (composition per kg product): Mn - 130,000 mg; Zn - 100,000 mg; Fe - 80,000 mg; Cu - 24,000 mg; - 2,000 g. 
quality in the laying hens. Hence, considering that the diet was formulated to have the same amounts of calcium and phosphorus and that the diet fiber level did not interfere significantly with the diet intake of the birds, it was inferred that calcium and phosphorus intake did not vary and consequently they did not influence laying hen bone growth and quality.

Scheideler et al. (1998) reported that adding fibrous feedstuffs to laying hen diets resulted in lower calcium and phosphorus digestibility of the diet. Considering that these minerals are the main bone constituents, it was expected that an increase in the proportion of fiber in the laying hen diets might hinder bone growth or quality in these birds, because less of these minerals was available for the bone metabolism. Although the availability of calcium and phosphorus in the laying hen diet could not be assessed, it was inferred that if mineral digestibility decreased in the diet with increase in the NDF level, from 145 to 185 , this was not sufficient to damage the growth and quality of the bones assessed.
Absence of significant influence of alterations in laying hen feeding in the growth phase on the bone quality was also reported by Santos (2008) who assessed the effect of three feeding programs (supplying 95, 100 and 105\% of the requirements proposed in the management manuals) for light-weight (Hy Line W36) and medium-weight (Hy Line Brown) birds and reported that the feeding programs did not influence the tibia fracture resistance in laying hens in the 16 th week of age.

Regarding the effect of strain on the parameters measured in the 17 th week of age, significant differences were observed for femur length, weight and composition and tibia weight, Seedor index and composition. However, bone length, resistance and deformity did not vary significantly between the strains.

The medium-weight birds presented larger, heavier femurs with a greater dry matter content and lower mineral and protein content than the light-weight birds, but there was no significant difference in Seedor index, resistance and bone deformity between the strains. For the tibia,

Table 2 - Effect of different neutral detergent fiber (NDF) levels on the bone quality and composition of the femur and tibia of light-weight and medium-weight laying hens in the 17 th week of age

\begin{tabular}{|c|c|c|c|c|c|c|c|c|}
\hline \multirow[b]{2}{*}{ Item } & \multicolumn{8}{|c|}{ Variables } \\
\hline & $\begin{array}{l}\text { Weight } \\
(\mathrm{g})\end{array}$ & $\begin{array}{l}\text { Length } \\
(\mathrm{mm})\end{array}$ & $\begin{array}{l}\text { Seedor index } \\
(\mathrm{mg} / \mathrm{mm})\end{array}$ & $\begin{array}{l}\text { Resistance } \\
\left(\mathrm{kgf} / \mathrm{cm}^{2}\right)\end{array}$ & $\begin{array}{l}\text { Deformity } \\
\text { (mm) }\end{array}$ & $\begin{array}{l}\text { Dry matter } \\
(\mathrm{g} / \mathrm{kg})\end{array}$ & $\begin{array}{c}\text { Mineral } \\
\text { matter }(\mathrm{g} / \mathrm{kg})^{1}\end{array}$ & $\begin{array}{l}\text { Crude protein } \\
\qquad(\mathrm{g} / \mathrm{kg})^{1}\end{array}$ \\
\hline \multicolumn{9}{|c|}{ Femur } \\
\hline \multicolumn{9}{|l|}{ NDF levels (g/kg) } \\
\hline 145.0 & 6.37 & 80.95 & 78.69 & 8.76 & 3.46 & 712.1 & 415.6 & 331.6 \\
\hline 165.0 & 6.17 & 80.12 & 76.43 & 10.63 & 3.26 & 704.5 & 432.3 & 317.9 \\
\hline 185.0 & 6.17 & 80.95 & 76.21 & 9.07 & 3.45 & 719.8 & 385.8 & 324.8 \\
\hline \multicolumn{9}{|l|}{ Strain } \\
\hline Light & $6.03 b$ & $79.55 b$ & 75.80 & 8.62 & 3.52 & $694.2 b$ & $435.9 a$ & $328.6 \mathrm{a}$ \\
\hline Medium-weight & $6.44 \mathrm{a}$ & $81.79 a$ & 78.73 & 10.35 & 3.25 & $730.0 \mathrm{a}$ & $386.5 b$ & $320.9 b$ \\
\hline \multicolumn{9}{|l|}{ Effects } \\
\hline Level & 0.578 & 0.589 & 0.537 & 0.225 & 0.721 & 0.622 & 0.112 & 0.214 \\
\hline Strain & $0.039 *$ & $0.008^{*}$ & 0.132 & 0.173 & 0.237 & $0.017^{*}$ & $0.011^{*}$ & $0.029 *$ \\
\hline Level $\times$ strain & 0.399 & 0.741 & 0.333 & 0.655 & 0.333 & 0.881 & 0.864 & 0.942 \\
\hline Coefficient of variation $(\%)$ & 7.17 & 2.26 & 5.58 & 23.47 & 16.41 & 4.69 & 10.30 & 4.61 \\
\hline \multicolumn{9}{|c|}{ Tibia } \\
\hline \multicolumn{9}{|c|}{ Total digestible nutrients levels (g/kg) } \\
\hline 145.0 & 7.57 & 116.01 & 65.25 & 6.04 & 3.19 & 785.2 & 411.3 & 318.5 \\
\hline 165.0 & 7.09 & 115.61 & 61.32 & 5.96 & 3.01 & 771.4 & 424.5 & 313.0 \\
\hline 185.0 & 7.42 & 117.27 & 63.27 & 5.96 & 3.33 & 793.6 & 407.2 & 307.7 \\
\hline \multicolumn{9}{|l|}{ Strain } \\
\hline Light & $6.97 \mathrm{~b}$ & 115.96 & $60.10 \mathrm{~b}$ & 6.29 & 3.41 & $766.7 b$ & $429.0 \mathrm{a}$ & $317.8 \mathrm{a}$ \\
\hline Medium-weight & $7.76 \mathrm{a}$ & 116.63 & $66.53 \mathrm{a}$ & 5.68 & 2.94 & $800.2 \mathrm{a}$ & $399.7 b$ & $308.3 b$ \\
\hline \multicolumn{9}{|l|}{ Effects } \\
\hline Level & 0.284 & 0.397 & 0.332 & 0.994 & 0.485 & 0.364 & 0.470 & 0.134 \\
\hline Strain & $0.005^{*}$ & 0.513 & $0.007^{*}$ & 0.362 & 0.142 & $0.015 *$ & $0.023^{*}$ & $0.037^{*}$ \\
\hline Level $\times$ strain & 0.577 & 0.979 & 0.572 & 0.676 & 0.618 & 0.933 & 0.747 & 0.594 \\
\hline Coefficient of variation $(\%)$ & 8.12 & 2.14 & 8.04 & 26.57 & 16.48 & 3.90 & 6.96 & 3.27 \\
\hline
\end{tabular}

Means followed by different letters in the column differ by the SNK (5\%) test.

${ }^{1}$ Values expressed on the dry matter.

* Significant effect at $5 \%$ probability $(\mathrm{P}<0.05)$; values expressed on a dry matter basis 
medium-weight birds presented significantly heavier bone, with greater Seedor index, greater dry matter content and lower mineral and protein content than the light-weight birds, but there was no significant difference in the bone resistance and deformity between the strains.

There are reports in the literature regarding the differences between white egg laying strains (light-weight birds) and brown egg laying strains (medium-weight birds) regarding bone development and quality. However, variations in experimental conditions, especially bird age, have frequently caused divergences in results. However, according to Whitehead (2004), genetic divergence is well demonstrated in bone development and quality among laying hen strains and this should be considered in current genetic breeding programs. According to this researcher, the difference in bone qualities between strains might occur due to greater capacity for depositing structural bone matter in the growth phrase presented by some strains, and also by the differences in the structural quality because a greater reticulate in the bone cartilage matrix contributes to greater fracture resistance of the bones.

According to Rath et al. (2000) data from some research studies have suggested that birds with genetic potential for greater body weight may present larger and more resistant bones. Bishop et al. (2000) reported that bone resistance correlates positively with bird live weight, indicating that heavier birds tend to have stronger bones, although sometimes they are not strong enough to resist excess weight. These facts explain the greater femur size and weight and greater tibia weight and density measured by the Seedor index of the medium-weight birds.

The results obtained in the present research for the bone quality of the strain, measured by fracture resistance, were in line with findings by Silversides et al. (2006), who assessed bone quality of three genetic groups - commercial strain of white egg laying hens (Babcock 300); brown egg laying hens (Isa Brown); and brown egg laying hens that had not undergone genetic selection. According to the researchers, there were no significant differences in the fracture resistance of the humerus on the 15th day of life among the strains. Vargas Junior et al. (2004) studied the calcium and phosphorus nutritional requirements of light repositioning birds (Hy Line W36) and medium-weight birds (Hy Line Brown) in the 13-20 week phase and observed that the strains responded similarly to the calcium and phosphorus levels in the diet. Comparison of the lightweight and medium-weight birds showed that, on average, medium-weight birds had greater bone resistance values compared with light-weight birds. Santos (2008) reported that light-weight birds (Hy Line W 36) presented tibia with greater fracture resistance than the medium-weight birds (Hy Line Brown) at all ages.

The differences in the bone composition of the strains used in the present research can be attributed to the growth characteristics of each strain. According to Neme (2006) white birds are earlier and therefore reach sexual maturity earlier than the brown birds, because they have higher body growth rates in a shorter time and also protein deposition and body ash rates. Extending these events to bone growth, light-weight birds may, at a certain moment of the growth curve, present bone with greater content of these constituents.

The assessment of the bird bones in the 35th week of age (Table 3) showed that there was no significant interaction between the factors NDF level and strain for all the variables assessed and that the NDF levels in the diet received by the laying hens in the growth phase (7th to 17 th weeks) did not significantly influence the bone growth, quality and composition of the femur and tibia of the laying hens at this age.

Bone quality at the start of the laying cycle has been considered fundamental for the bone quality of laying hens throughout the laying phase and to the end of the production cycle, mainly for birds selected for high production, because greater mineral mobilization for egg shell formation might lead to less bone resistance in these birds compared with less productive birds (Silversides et al., 2006).

In this context, considering that there was no significant influence of the NDF level in the growth diet on the bone growth and quality parameters measured at the end of the growth phase and that in the laying phase birds were fed the same laying hen diet and did not present significant differences in diet intake and egg production, these results can be considered as expected. Regarding the strain effect, significant differences were observed in the femur and tibia weight, length, Seedor index and bone formation and in the femur protein content and tibia mineral content. However, resistance did not vary significantly between the strains.

Medium-weight birds presented larger and heavier femur and tibia with greater Seedor index and less deformity than the light-weight birds. These birds also presented femur with lower protein content and tibia with greater ash content.

As reported previously, at the end of the growth phase, medium-weight birds presented larger and heavier bones than light-weight birds, which was attributed to the differences in growth between strains, so heavier birds had larger and heavier bones (Bishop et al., 2000; Rath et al., 2000). 
According to Whitehead (2004), differences in bone quality can appear at different ages and higher quality bone at the end of the laying period depends on two factors: greater bone formation capacity in the growth phase and lower bone reabsorption intensity during the laying phase. Riczu et al. (2004) assessed bone quality at the end of the production cycle of white egg (Shaver 2000) and brown egg (Shaver 597) laying hens and reported that brown egg laying hens presented femur with a similar length to those of the white egg laying hens, while the weight and fracture resistance were greater. According to the authors, the greater femur weight of brown birds indicated that the total bone thickness was greater in these birds and suggested a greater quantity of bone tissue in the same length, which increase density and consequently bone resistance.

According to Silversides et al. (2006), although there were no significant differences between the strains in the fracture resistance values in the humerus in the 15 th week of life, it was observed among the birds that were genetically bred that with advancing age, brown laying hens (Isa Brown) presented more resistant bones than white laying hens (Babcock 300). According to the authors, reduced bone resistance with age is associated with selection for high egg production, while the greater bone resistance of the brown egg laying hens is associated with the larger body size of these birds. However, Santos (2008) reported that light-weight birds (Hy Strain White 36) presented greater fracture resistance than medium-weight birds (Hy Strain Brown) at all ages and that white egg laying hens (lightweight birds) lost less bone mass as their age advanced.

It should be emphasized that greater density in a bone will not always result in greater resistance. In the present research, at all the ages, medium-weight birds presented bone with greater mean density by the Seedor index. However, this was not translated to significant difference in fracture resistance, as reported by some researchers.

Similar to density, the greater proportion of mineral matter and protein in the bone of the light-weight birds did not result in significant increase in bone resistance.

The results obtained in the present research corroborated observations presented by Rath et al. (2000). According to these researchers, bone is a complex tissue and bone

Table 3 - Effect of different neutral detergent fiber levels in the growth diet on bone quality and composition of the femur and tibia of lightweight and medium-weight laying hens in the 35 th week of life

\begin{tabular}{|c|c|c|c|c|c|c|c|c|}
\hline \multirow[b]{2}{*}{ Item } & \multicolumn{8}{|c|}{ Variables } \\
\hline & $\begin{array}{l}\text { Weight } \\
(\mathrm{g})\end{array}$ & $\begin{array}{l}\text { Length } \\
(\mathrm{mm})\end{array}$ & $\begin{array}{l}\text { Seedor index } \\
(\mathrm{mg} / \mathrm{mm})\end{array}$ & $\begin{array}{c}\text { Resistance } \\
\left(\mathrm{kgf} / \mathrm{cm}^{2}\right)\end{array}$ & $\begin{array}{l}\text { Deformity } \\
(\mathrm{mm})\end{array}$ & $\begin{array}{l}\text { Dry matter } \\
(\mathrm{g} / \mathrm{kg})\end{array}$ & $\begin{array}{c}\text { Mineral } \\
\text { matter }(\mathrm{g} / \mathrm{kg})^{1}\end{array}$ & $\begin{array}{l}\text { Crude protein } \\
(\mathrm{g} / \mathrm{kg})^{1}\end{array}$ \\
\hline \multicolumn{9}{|c|}{ Femur } \\
\hline \multicolumn{9}{|c|}{ Neutral detergent fiber levels $(\mathrm{g} / \mathrm{kg})$} \\
\hline 145.0 & 6.10 & 80.33 & 75.93 & 7.35 & 2.69 & 601.0 & 470.3 & 340.0 \\
\hline 165.0 & 6.20 & 80.56 & 76.96 & 6.67 & 2.55 & 637.0 & 451.0 & 331.3 \\
\hline 185.0 & 6.24 & 80.71 & 77.31 & 9.29 & 2.24 & 634.0 & 455.1 & 323.6 \\
\hline \multicolumn{9}{|l|}{ Strain } \\
\hline Light & $5.67 \mathrm{~b}$ & $78.15 b$ & $72.55 b$ & 8.70 & $2.74 \mathrm{a}$ & 613.6 & 467.5 & $344.9 \mathrm{a}$ \\
\hline Medium-weight & $6.67 \mathrm{a}$ & $80.24 \mathrm{a}$ & $83.12 \mathrm{a}$ & 6.26 & $2.27 b$ & 634.4 & 450.0 & $324.9 b$ \\
\hline \multicolumn{9}{|l|}{ Effects } \\
\hline Level & 0.587 & 0.592 & 0.457 & 0.118 & 0.297 & 0.268 & 0.259 & 0.073 \\
\hline Strain & $0.039 *$ & $0.022 *$ & $0.007 *$ & 0.222 & $0.023 *$ & 0.293 & 0.191 & $0.007^{*}$ \\
\hline Level $\times$ strain & 0.743 & 0.732 & 0.945 & 0.078 & 0.065 & 0.653 & 0.116 & 0.045 \\
\hline Coefficient of variation $(\%)$ & 6.13 & 1.83 & 5.35 & 35.39 & 17.93 & 7.55 & 5.25 & 4.82 \\
\hline \multicolumn{9}{|c|}{ Tibia } \\
\hline \multicolumn{9}{|c|}{ Neutral detergent fiber levels (g/kg) } \\
\hline 145.0 & 7.16 & 115.79 & 61.83 & 5.75 & 2.58 & 676.4 & 471.2 & 337.5 \\
\hline 165.0 & 7.39 & 115.70 & 63.87 & 5.47 & 1.90 & 713.0 & 446.0 & 322.6 \\
\hline 185.0 & 7.26 & 116.95 & 62.07 & 4.85 & 2.28 & 701.2 & 458.9 & 315.5 \\
\hline \multicolumn{9}{|l|}{ Strain } \\
\hline Light & $6.54 \mathrm{~b}$ & $114.43 b$ & $57.15 b$ & 5.87 & $2.56 \mathrm{a}$ & 698.3 & $472.5 \mathrm{a}$ & 328.6 \\
\hline Medium-weight & $8.00 \mathrm{a}$ & $117.87 \mathrm{a}$ & $67.87 \mathrm{a}$ & 4.87 & $1.95 b$ & 695.5 & $444.8 b$ & 321.8 \\
\hline \multicolumn{9}{|l|}{ Effects } \\
\hline Level & 0.825 & 0.419 & 0.836 & 0.443 & 0.109 & 0.177 & 0.140 & 0.129 \\
\hline Strain & $0.001 *$ & $0.010 *$ & $0.001^{*}$ & 0.089 & $0.026^{*}$ & 0.859 & $0.012 *$ & 0.290 \\
\hline Level $\times$ strain & 0.968 & 0.694 & 0.981 & 0.459 & 0.733 & 0.599 & 0.180 & 0.405 \\
\hline Coefficient of variation $(\%)$ & 8.26 & 2.70 & 7.70 & 26.23 & 27.15 & 3.90 & 6.96 & 3.27 \\
\hline
\end{tabular}

Means followed by different letters in the column differ by the SNK test $(5 \%)$.

${ }^{1}$ Values expressed on the dry matter.

* Significant effect of $5 \%$ probability $(\mathrm{P}<0.05)$; values expressed on the dry matter. 
tissue density and resistance are related to the physical aspect (shape, size and mass), architecture (direction of the collagen fibers) and material properties (molecular matrix), so resistance may differ in bones that present similar physical properties and chemical composition, as can be verified in similar resistance of bones that present differences in some physical properties or composition.

It seems that the bone differences between the strains need to be better understood, especially regarding the form of assessment, considering the divergent results.

\section{Conclusions}

Diets for laying hen in the growth phase, between the 7th and 17th weeks, can contain up to $185 \mathrm{~g} / \mathrm{kg}$ neutral detergent fiber without bringing problems to bone development or quality in birds at the end of the growth period and in the 35 th week of age. The birds of the strains analyzed presented similar responses to increase in neutral detergent fiber in the growth diet.

\section{References}

AERNI, V.; EL-LETHEY, H.; WECHSLER, B. Effect of foraging material and food form on feather pecking in laying hens. British Poultry Science, v.41, p.16-21, 2000.

BRUNO, L.G.D. Desenvolvimento ósseo em frangos de corte: Influência da restrição alimentar e da temperatura ambiente. 2002. 72f. Tese (Doutorado em Zootecnia) - Universidade Estadual Paulista, Jaboticabal.

BISHOP, S.C.; FLEMING R.H.; MCCORMACK, H.A. et al. The inheritance of bone characteristics affecting osteoporosis in laying hens. British Poultry Science, v.41, p.33-46, 2000.

EL-LETHEY, H.; AERNI, V.; JUNGI, T.W. et al. Stress and feather pecking in laying hens in relation to housing conditions. British Poultry Science, v.41, p.22-28, 2000.

GREGORY, N.G.; WILKINS L.J. Broken bones in domestic fowl: Handling and processing damage in end-of lay battery hens. Poultry Science, v.30, p.555-562, 1989.

GONZALEZ-ALVARADO, J.M.; JIMÉNEZ-MORENO, E.; LÁZARO, R. et al. Effect of type of cereal, heat processing of the cereal, and inclusion of fiber in the diet on productive performance and digestive traits of broilers. Poultry Science, v.86, p.1705-1715, 2007.
JERACI, J.L.; VAN SOEST, P.J. Improved methods for analysis and biological characterization of fiber. Advances in Experimental Medicine and Biology, v.270, p.245-263, 1990.

NEME, R.; SAKAMURA, N.K.; FUKAYAAMA, E.H. et al. Curvas de crescimento e de deposição dos componentes corporais em aves de postura de diferentes linhagens. Revista Brasileira Zootecnia, v.35, n.3, p.1091-1100. 2006.

RATH, N.C.; HUFF, G.R.; HUFF, W.E. et al. Factors regulating bone maturity and strength in poultry. Poultry Science, v.79, n.7, p.1024-1032, 2000.

RICZU, C.M.; SAUNDERS-BLADES, J.L.; YNGVESSON, A.K. et al. End-of-cycle bone quality in white and brown egg laying hens. Poultry Science, v.83, p.375-383, 2004.

ROSTAGNO, H.S.; ALBINO, L.F.T.; DONZELE, J.L. et al. Tabelas brasileiras para aves e suínos: Composição de alimentos e exigências nutricionais. 2.ed. Viçosa, MG: UFV, 2005. 186p.

SANTOS, A.L. Desempenho, crescimento, qualidade do ovo, composição corporal e características reprodutivas e ósseas de poedeiras submetidas a diferentes programas nutricionais. 2008. 175f. Tese (Doutorado em Zootecnia) - Faculdade de Zootecnia e Engenharia de Alimentos/Universidade de São Paulo, Pirassununga.

SAKOMURA, N.K.; ROSTAGNO, H.S. Métodos de pesquisa em nutrição de monogástricos. Jaboticabal: FUNEP, 2007. 283p

SCHEIDELER, S.E.; JARONI, D.; PUTHPONGSIRIPRON, U. Strain, fibers ource, and enzyme supplementation effectosn pullet gutm orphologanyd, subsequent growthnu, trienutt ilization, layerp erformance. Journal Applied Poultry Research, v.7, p.359-371. 1998.

SEEDOR, J.G. The biophosphanate alendronate (MK-217) inhibit bone loss due to ovariectomy in rats. Bone and Mineral Research, v.6, p.339-346, 1991.

SILVA, D.J.; QUEIROZ, A.C. Análise de alimentos: métodos químicos e biológicos. 3.ed. Viçosa, MG: Editora UFV, 2002. $165 \mathrm{p}$.

SILVERSIDES, F.G.; KORVER, D.R., BUDGELL, K.L. Effect of strain of layer and age at photostimulation on egg production, egg quality, and bone strength. Poultry Science, v.85, p.1136-1144, 2006.

VAN SOEST, P.; WINE, R.H. Use of detergents in the analysis of fibrous feeds. IV. Determination of plant cell wall constituents. Journal of the Official Agricultural Chemists, v.50, p.50-55, 1967.

VARGAS JUNIOR, J.G.; ALBINO, L.F.T.; ROSTAGNO, H.S. et al. Níveis nutricionais de cálcio e de fósforo disponível para aves de reposição leves e semipesadas de 13 a 20 semanas de idade. Revista Brasileira de Zootecnia, v.33, n.5, p.1263-1273, 2004.

WARPECHOWSKI, M.B. Efeito do nível e fonte de fibra sobre a concentração e a utilização da energia metabolizável de dietas para frangos de corte em crescimento. 2005. 179f. Tese (Doutorado em Zootecnia) - Faculdade de Agronomia/Universidade Federal do Rio Grande do Sul, Porto Alegre.

WHITEHEAD C.C. Overview of bone biology in the egg-laying hen. Poultry Science, v.83, p.193-199, 2004. 